\title{
KONSTRUKSI HISTORIS HUKUM PIDANA ISLAM (FORMULASI HUKUM PIDANA ISLAM DALAM LINTASAN SEJARAH)
}

\author{
Sam'un \\ Dosen Tetap Fakultas Syariah IAIN Sunan Ampel Surabaya
}

\begin{abstract}
Abstrak: Pembaharuan hukum pidana Islam pada hakekatnya merupakan upaya ikhtiyar ijtihadiyah dalam melakukan rekontruksi, reorientarsi dan reformasi hukum pidana yang diharapkan terdapat sinergisitas dan kesesuaian antara tuntunan syari'at dengan nilai-nilai sentral sosio politik, sosio filosofis dan sosio kultural ummat Islam yang secara faktual tersebar diberbagai belahan dunia dan senantiasa berkembang secara dinamis sesuai dengan gerak zaman dan laju peradaban sejarah kehidupan manusia. Artikulasi dan ekspresi ummat Islam dalam menerapkan hukum pidana Islam seringkali menunjukkan karakteristik yang berbeda dengan ketentuan dhahir nash syari'at ketika bersentuhan dengan realitas sosial- faktual yang terjadi di tengahtengah masyarakat, hal tersebut dapat dilacak kesahehannya seperti yang pernah dilakukan oleh khalifah Umar bin Al-Khattab yang tidak memotong tangan pencuri karena kondisi masyarakat lagi paceklik. Hal tersebut dapat dikategorikan sebagai " pembaharauan atau inovasi" hukum pidana Islam dalam konteks reorientasi tafsir dan pemahaman hukum potong tangan bagi pencuri sebagaimana yang ditegaskan dalam al-Qur'an. Dengan demikian lacakan historis penerapan hukum pidana Islam mulai zaman Rasulullah Muhammad SAW hingga sekarang khususnya penerapan hukum pidana Islam yang diberlakukan di Nusantara (Indonesia) merupakan keharusan ilmiyah yang harus dilakukan guna memahami karakteristik pembaharuan hukum pidana Islam dari masa ke masa.
\end{abstract}

Kata Kunci: Pembaharuan, hukum pidana Islam, historisitas, fenomenologis

\section{Pendahuluan}

Pembahuruan hukum Pidana Islam dapat dipahami sebagai upaya modernisasi,atau suatu upaya yang dilakukan untuk 
mengadakan atau menciptakan sesuatu yang baru terhadap kreasi ijtihad para fukaha yang terkoodifikasi dalam kitab yang dijadikan dasar hukum dalam menerapkan syariat berdasarkan kebutuhan masyarakat.

Allah SWT telah menetapkan hukum-hukum uqubat dalam peraturan Islam sebagai "pencegah" dan "penebus". Sebagai pencegah, karena ia berfungsi mencegah manusia dari tindakan kriminal; dan sebagai penebus, karena ia berfungsi menebus dosa seorang muslim dari azab Allah di hari kiamat.

Keberadaan uqubat dalam Islam yang berfungsi sebagai pencegah telah ditegaskan dalam al-Qur'an;

"Dan dalam qishaash itu ada (jaminan kelangsungan) hidup bagimu, Hai orang-orang yang berakal, supaya kamu bertakwa." (QS: Al-Baqarah: 179)

Yang dimaksud dengan "ada jaminan kehidupan" sebagai akibat pelaksanaan qishash adalah melestarikan kehidupan masyarakat, bukan kehidupan sang terpidana. Sebab, bagi dia adalah kematian. Sedangkan bagi masyarakat yang menyaksikan penerapan hukuman tersebut (orang-orang yang berakal) tentulah menjadi tidak berani membunuh, sebab konsekuensi membunuh adalah dibunuh. Demikian pula halnya dengan hukumanhukuman lainnya, sebagai bentuk pencegahan terjadinya kriminalitas yang merajalela.

Yang dimaksud dengan tindakan kriminal adalah suatu perbuatan yang dipandang tercela oleh syara'. Oleh karena itu, suatu perbuatan tidak dapat dikategorikan tindakan kriminal, kecuali apabila telah ditetapkan melalui nash syara' (al-Qur'an, hadits, dan apa-apa yang ditunjuk keduanya). Jika manusia melanggar perintah/larangan Allah, berarti dia telah melakukan perbuatan tercela, dan dianggap telah melakukan tindakan kriminal, sehingga harus dijatuhi hukuman atas kriminalitas yang dilakukannya. Sebab, tanpa pemberlakuan hukuman bagi para pelanggar, hukum tidak akan memiliki arti apa-apa. Suatu 
perintah tidak akan bernilai apa-apa jika tak ada balasan (hukuman) bagi pelanggar yang mengabaikan perintah tersebut.

Syariat Islam telah menjelaskan bahwa pelaku kriminalitas akan mendapatkan hukuman, baik hukuman di dunia maupun hukuman di akhirat. Allah akan mengazab mereka di akhirat, dengan hukuman yang nyata, sebagaimana firman Nya:

"Dan orang-orang kafir bagi mereka neraka jahannam. mereka tidak dibinasakan sehingga mereka mati dan tidak (pula) diringankan dari mereka azabnya. Demikianlah kami membalas setiap orang yang sangat kafir." (QS. Faathir: 36)

Allah SWT maha pemurah bagi hambaNya yang beriman terhadap seluruh firman-firmanNya, disediakan alternatif yang mampu "menebus" dosa-dosanya di akhirat, yakni berupa serangkaian hukum pidana di dunia. Allah telah menjelaskan dalam Qur'an dan Hadits, baik secara global maupun terperinci, hukum-hukum pidana bagi setiap pelaku kriminalitas. Seperti: mencuri, berzina, mabuk, merontokkan gigi orang lain, dan sebagainya. Allah memberikan wewenang pelaksanaan hukuman tersebut kepada Imam / Pemimpin dan wakil-wakilnya (para hakim), yaitu dengan menerapkan sangsi-sangsi yang telah ditetapkan oleh Negara, baik berupa hudud, ta'zir, maupun kafarat (denda).

Dalam upaya memahami secara komprehensif terkait perkembangan dan pembaharuan hukum Islam, maka artikel ini berusaha mendeskripsikan secara kronologis-historis dan fenomenologis formulasi perkembangan dan pembaharuan hukum pidana Islam dari fase awal hingga saat sekarang, terutama dalam konteks ke Indonesiaan.

\section{Konstruksi Teoritik Hukum Pidana Islam}

Islam merupakan agama yang universal dan rahmatal lil alamin, untuk siapa saja, di mana saja berada dan kapan saja. Agama Islam merupakan satu-satunya agama yang mampu menyesuaikan diri dalam kondisi apapun tanpa menghilangkan

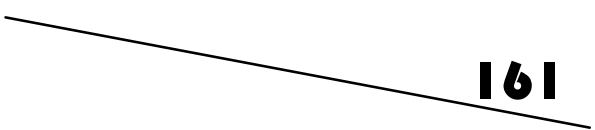


nilai-nilai dasar (substansial) dari ajaran Islam yang luhur. Hal itulah yang menyebabkan kenapa Islam dapat berlaku selamalamanya dan di manapun (al-Islamu haqqun likulli zaman wa makan), tidak musnah termakan zaman yang senantiasa dinamis dan menuntut perubahan, terutama terkait dengan persoalan hukum, karena konstruksi dasar yang dijadilkan pedoman adalah konsep al-Hukmu yaduru bi al-Illatihi wujudan wa adaman (hukum itu berjalan seiring ada dan ketiadaan Illah Hukum ) serta Taghayyurul ahkam bitaghayyuril azminati wal amkinati (berubahnya hukum terkait dengan perubahahan situasi/zaman dan kondisi/ tempat).

Dalam konteks khazanah hukum positif, hukum menurut isinya dapat dibagi menjadi Hukum Privat (Hukum Sipil) dan Hukum Publik. Hukum Sipil dalam arti luas meliputi Hukum Perdata (Burgelijkrecht) dan Hukum Dagang (Handelsrecht), sedangkan dalam arti sempit meliputi Hukum Perdata saja. Hukum Publik terdiri dari Hukum Tata Negara, Hukum Administrasi Negara, Hukum Pidana, dan Hukum Internasional.

Berbeda dengan hukum positif, hukum Islam tidak membedakan dengan tajam antara hukum perdata dengan hukum publik. Ini disebabkan karena menurut sistem hukum Islam, pada hukum perdata terdapat segi segi publik dan pada hukum publik ada segi segi perdatanya. Itulah sebabnya maka dalam hukum Islam tidak dibedakan kedua bidang hukum itu. Yang disebutkan hanyalah bagian bagiannya saja, seperti misalnya; Munakahat, Wirosah, Mu'amalat dalam arti khusus, jinayat atau uqubah, al ahkam as sulthoniyyah, dan lainnya.

Hukum Pidana Islam sering disebut dalam fiqh dengan istilah jinayat atau jarimah. Jinayat dalam istilah hukum sering disebut dengan delik atau tindak pidana. Jinahah merupakan bentuk verbal noun (mashdar) dari kata jana. Secara etimologi jana berarti berbuat dosa atau salah, sedangkan jinayah diartikan perbuatan dosa atau perbuatan salah. Secara terminologi kata jinayat mempunyai beberapa pengertian, seperti yang diungkapkan oleh Abd al Qodir Awdah bahwa jinayat adalah perbuatan yang 
dilarang oleh syara' baik perbuatan itu mengenai jiwa, harta benda, atau lainnya. ${ }^{1}$

Menurut A. Jazuli, pada dasarnya pengertian dari istilah Jinayah mengacu kepada hasil perbuatan seseorang. Biasanya pengertian tersebut terbatas pada perbuatan yang dilarang. ${ }^{2} \mathrm{Di}$ kalangan fuqoha', perkataan Jinayat berarti perbuatan perbuatan yang dilarang oleh syara'. Meskipun demikian, pada umunya fuqoha' menggunakan istilah tersebut hanya untuk perbuatan perbuatan yang terlarang menurut syara', Meskipun demikian, pada umumnya fuqoha' menggunakan istilah tersebut hanya untuk perbuatan perbuatan yang mengancam keselamatan jiwa, seperti pemukulan, pembunuhan dan sebagainya. Selain itu, terdapat fuqoha' yang membatasi istilah Jinayat kepada perbuatan perbuatan yang diancam dengan hukuman hudud dan qishash, tidak temasuk perbuatan yang diancam dengan ta'zir. Istilah lain yang sepadan dengan istilah jinayat adalah jarimah, yaitu larangan larangan syara' yang diancam Allah dengan hukuman had atau ta'zir.

Sebagian fuqoha menggunakan kata jinayat untuk perbuatan yang yang berkaitan dengan jiwa atau anggota badan, seperti membunuh, melukai dan lain sebagainya. Dengan demikian istilah fiqh jinayat sama dengan hukum pidana. Haliman dalam disertasinya menyebutkan bahwa yang dimaksud dengan hukum pidana dalam syari'at Islam adalah ketentuan-ketentuan hukum syara' yang melarang untuk berbuat atau tidak berbuat sesuatu, dan pelanggaran terhadap ketentuan hukum tersebut dikenakan hukuman berupa penderitaan badan atau harta.

Dalam tulisan artikel ini, akan lebih di fokuskan pembahasan dan kajiannya pada aspek Pembaharuan hukum Pidana Islam, sehingga aspek kajian historis dan fenomelologis menjadi kontain

' Audah, Abdul Qodir. Tasyri' Jina'l Islami. Beirut: Al Muassasah Al Risalah. 2000 M, hal. 7

2 Djazuli, H.A. 2000. Fiqh Jinayat (Menanggulangi Kejahatan dalam Islam).. Jakarta: PT Raja Grafindo Persada, hal I I

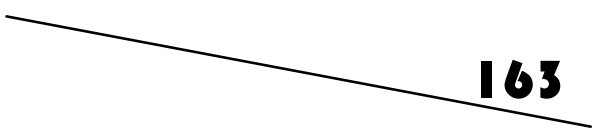


dalam artikel ini disamping terkait dengan aspek wilayah spesifikasi dari hukum pidana Islam itu sendiri.

\section{Sketsa Hukum Pidana Islam pada Masa Rasulullah SAW}

Konstruksi hukum Pidana Islam Generasi awal sebelum asru al-Tadwin tidak dapat di pisahkan dari masa Nubuwwah, karena pada masa Rasulullah SAW inilah proses awal pewahyuan hukum yang menjadi asas atau dasar rujukan shaheh pemberlakukan hukum pidana Islam yang tidak lain bersumber dari Nas al-Qur'an dan al- Hadis. Masa Rasulullah berlangsung kurang lebih 22 tahun beberapa bulan. Akan tetapi periode ini membawa pengaruh-pengaruh yang besar dalam pembentukan peradaban Islam saat ini. Periodeisasi pembentukan hukum pada fase Rasulullah dapat di klasifikasikan menjadi :

\section{1) Periode Makkah}

Periode ini berlangsung kurang lebih selama 12 tahun beberapa bulan, semenjak beliau diangkat sebagai Rasul sampai waktu hijrahnya. Pada fase ini kaum muslimin jumlahnya sedikit dan masih lemah, belum merupakan suatu umat dan belum mempunyai pemerintahan. Perhatian rasul pada fase ini diarahkan kepada penyebaran dakwah ketauhidan dan berusaha memalingkan umat manusia dari menyembah berhala, menjaga diri dari gangguan orang-orang yang sengaja menghalangi dakwah Islam, orang-orang yang memperdayakan orang-orang yang beriman kepada ajarannya. Nabi Juga mengajarkan larangan memakan daging hewan yang disembelih atas nama berhala, melihat undian nasib dengan anak panah, melakukan perbuatan zina dan lain sebagainya. Secara spesifik wahyu Allah SWT yang turun pada periode mekkah secara khusus menyangkut bidang aqidah, akhlak, dan ibadah serta suri tauladan dari sejarah ummat yang dahulu.

2) Periode Madinah dan dasar Hukum Pidana dalam al-Qur'an

Periode ini berlangsung selama kurang lebih 10 tahun, dimulai dari masa hijrah Nabi Muhammad SAW Hingga 
wafatnya. Selama Nabi berada di Madinah, dakwah yang dilakukan Rasulullah lebih efektif dibandingkan dengan di Mekkah yang ditandai dengan banyaknya orang-orang yang beriman. Oleh karena itu, ayat-ayat Al-Quran yang turun banyak mengandung hukum 'amaliyah, baik yang berkenaan dengan hidup individual maupun masyarakat yang dapat dipastikan sangat memerlukan ketentuan hukum dan lembaga pengadilan. Islam telah terbina menjadi umat, dan telah merupakan satu pemerintahan, media-media dakwah telah berjalan lancar. Keadaan mendesak adanya tasyri' dan undang-undang mengatur hubungan antar individu satu dengan yang lainnya, selaku umat yang berkembang serta mengatur hubungan-hubungan mereka dengan yang lain, baik di masa damai maupun perang. Untuk ini maka disyari'atkanlah di Madinah hukum-hukum Perdata maupun Pidana.

Pada masa Rasulullah SAW sumber dalam penetapan atau pembinaan hukum Islam ada dua yakni wahyu Allah SWT dan Hadis Rasulullah SAW sedangkan ijtihad yang dilakukan para sahabat pada waktu itu tidak dapat dijadikan dasar yang mutlak kecuali ada pengakuan dari Rasulullah SAW sendiri. Dasar dari penertapan hukum tersebut sebagaimana firman Allah SWT ;

"Sesungguhnya kami Telah menurunkan Kitab kepadamu dengan membawa kebenaran, supaya kamu mengadili antara manusia dengan apa yang Telah Allah wahyukan kepadamu, dan janganlah kamu menjadi penantang (orang yang tidak bersalah), Karena (membela) orang-orang yang khianat." (Q.S. An-Nisa': 105).

Dalam periode ini telah terkonstruksi aspek-aspek dasar pembentukan hukum, baik yang terkait dengan akidah dan Ibadah maupun yang terkait dengan mu'amalah yang termasuk didalamnya adalah hukum pidana Islam yang menjelaskan aturan dan sangsi bagi para pelaku kejahatan, kriminalitas dan perilaku yang merugikan kehidupan publik. ${ }^{3}$

${ }^{3}$ Wahbah Zuhaili, al-Qur'an al-karim; banaituhu al-tasyri'iyyah wa khasaisuhu al- hadlariyyat ( Dar al-Fikr, Bairut Libanon, 1993 ) hal . 5 I

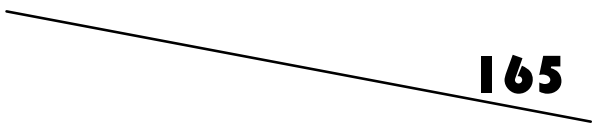


Beberapa contoh ayat al-Qur'an yang menjelaskan perihal hukum yang terkait dengan hukum pidana antara lain;

"Hai orang-orang yang beriman, diwajibkan atas kamu qishaash berkenaan dengan orang-orang yang dibunuh; orang merdeka dengan orang merdeka, hamba dengan hamba, dan wanita dengan wanita. Maka barangsiapa yang mendapat suatu pema'afan dari saudaranya, hendaklah (yang mema'afkan) mengikuti dengan cara yang baik, dan hendaklah (yang diberi ma'af) membayar (diat) kepada yang memberi ma'af dengan cara yang baik (pula). yang demikian itu adalah suatu keringanan dari Tuhan kamu dan suatu rahmat. barangsiapa yang melampaui batas sesudah itu, Maka baginya siksa yang sangat pedih." (QS. al-Baqarah: 178)

"Dan tidak layak bagi seorang mukmin membunuh seorang mukmin (yang lain), kecuali Karena tersalah (Tidak sengaja), dan barangsiapa membunuh seorang mukmin Karena tersalah (hendaklah) ia memerdekakan seorang hamba sahaya yang beriman serta membayar diat yang diserahkan kepada keluarganya (si terbunuh itu), kecuali jika mereka (keluarga terbunuh) bersedekah. jika ia (si terbunuh) dari kaum (kafir) yang ada perjanjian (damai) antara mereka dengan kamu, Maka (hendaklah si pembunuh) membayar diat yang diserahkan kepada keluarganya (si terbunuh) serta memerdekakan hamba sahaya yang beriman. barangsiapa yang tidak memperolehnya, Maka hendaklah ia (si pembunuh) berpuasa dua bulan berturut-turut untuk penerimaan Taubat dari pada Allah. dan adalah Allah Maha mengetahui lagi Maha Bijaksana. Dan barangsiapa yang membunuh seorang mukmin dengan sengaja Maka balasannya ialah Jahannam, kekal ia di dalamnya dan Allah murka kepadanya, dan mengutukinya serta menyediakan azab yang besar baginya." (QS : An-Nisa': 92-93)

"Sesungguhnya pembalasan terhadap orang-orang yang memerangi Allah dan rasul-Nya dan membuat kerusakan di muka bumi, hanyalah mereka dibunuh atau disalib, atau dipotong tangan dan kaki mereka dengan bertimbal balik, atau dibuang dari negeri (tempat kediamannya). yang demikian itu (sebagai) suatu penghinaan untuk mereka didunia, dan di akhirat mereka beroleh siksaan yang besar." (QS: al-Maidah: 33) 
Dari penjelasan kutipan beberapa ayat al-Qur'an diatas, para ulama' mengkatagorikan bahwa hukum pidana Islam atau yang dikenal dengan istilah Jarimah terklasifikasi menjadi tiga aspek yaitu ;

1. Pidana Hudud yaitu tindak pidana/kejahatan yang hukumannya telah di tetapkan oleh Allah SWT, Seperti Perzinahan, Perampokan, pencurian dan lainnya

2. Pidana Qishas yaitu tindak Pidana/kejahatan yang terkait dengan integritas Tubuh seperti Pembunuhan, Penganiyayaan, dan lainnya

3. Pidana Ta'zir yaitu Pidana yang hukuman atau sangsinya tidak ditetapkan oleh Allah SWT dan Rasulnya akan tetapi ditentukan oleh Pemerintah untuk kemaslahatan umum seperti Penghinaan dan lainnya

\section{Pembaharuan Hukum Pidana Islam Masa Khulafa' al Rasyidin}

Potret kebijakan hukum pidana yang dikukan oleh Para Khalifah Pengganti Rasulullah SAW sebagai mana yang telah digariskan oleh al- Qur'an dan Sunnah Nabi pada tataran implementasinya penuh dengan nuansa ijtihadi/pembaharuan yang bersemangatkan aplikasi maslahah, sebagaimana beberapa contoh kasus ini;

\section{1) Kebijakan Hukum Pidana Masa Khalifah Abubakar}

- Pada saat terjadi peristiwa di mana suatu keluarga pasangan suami isteri menjamu tamu seorang lelaki. Tak disangka, terjadilah perzinaan antara si lelaki itu dan gadis puteri pasangan suami isteri tersebut. Kasus ini dilaporkan kepada Khalîfah Abû Bakar al-Siddiq, dan Pada akhirnya Khalîfah memutuskan bahwa kedua orang pelaku dipidana dengan pidana cambuk 100 kali cambukan dan pidana pengasingan selama satu tahun. ${ }^{4}$

${ }^{4}$ Subhi Mahmasâni, Turâts al-Khulafâ' al-Râsyidin fi al-Figh wa al-Qadâ', (Beirut: Dâr al- Malâyîn, 1984), h. 219.

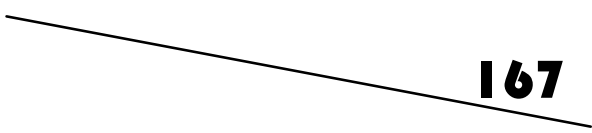


- Pada saat terjadi peristiwa di mana dua orang lelaki secara bersama-sama berbuat laku homoseksual di wilayah kekuasaan Gubernur Khalid ibn al-Walid. Maka, Gubernur menulis surat kepada Khalifah Abu Bakar al-Siddiq meminta putusan hukum tentang pelaku homoseksual. Khalifah akhirnya bermusyawarah dengan 'Ali ibn Abi Talib, Sahabat yang ahli hukum; dan 'Ali berpandangan keharusan eksekusi hukuman mati. Pandangan ini diamini oleh Khalifah, dan kemudian diinformasikan kepada Gubernur Khalid ibn al-Walid. ${ }^{5}$

- Khalifah Abu Bakar al-Siddiq mengambil kebijakan hukum bahwa pidana amputasi tangan bagi para pencuri dilakukan dengan memotong pergelangan tangan. ${ }^{6}$

- Khalifah Abu Bakar al-Siddiq pernah mengambil kebijakan hukum, yakni menetapkan pidana mati (pidana ta'zîr) atas orang yang menghina/mencela Nabi Muhammad saw. ${ }^{7}$

\section{2) Kebijakan Hukum Pidana Masa Khalifah Umar}

- Khalifah ‘Umar ibn al-Khattab menganulir eksekusi pidana hadd atas seorang perempuan yang berzina dengan seorang lelaki yang kepadanya ia meminta uang lantaran desakan kebutuhan hidup. 8

- Khalifah Umar ibn al-Khattab menghukum seorang lelaki dzimmiy yang memaksa seorang perempuan muslimah berzina dengan hukuman mati yang eksekusinya di kawasan Bait al-Maqdis.

- Khalifah 'Umar ibn al-Khattab mengambil kebijakan hukum, yakni orang murtad yang bersikukuh dengan

${ }^{5}$ Ibid, hal. 223

${ }^{6}$ Ibn Hazm al-Andalusi, al-Muhalla, (Kairo: Dâr al-Kutub al-'Arabiyyah, 1988), Juz ke-। I, butir masalah no. 2284

7 Ibrahim ibn Muhammad ibn Farhûn, Tabsirat al-Hukkâm, (Kairo: Dar al-Kutub al-'Arabiyyah, 1980), Juz ke-2, h. 206 dan 226.

${ }^{8}$ Muhammad ibn Ahmad al-Ansari al-Qurtubi, al-fâmi‘ li Ahkam al-Qur'an, (Kairo: Dâr al- Kutub al-'Arabiyyah, 1989), Juz ke-10, h. 185. 
kemurtadannya hanya boleh dijatuhi pidana penjara saja, tidak boleh dengan pidana mati. ${ }^{9}$

- Terjadi peristiwa di mana pada suatu hari Khalifah 'Umar ibn al-Khattab didatangi seorang laki-laki yang membawa pedang berlumuran darah, untuk meminta perlindungan kepada Khalifah; dan dari kejauhan terlihat rombongan orang yang mengejarnya. Setelah tiba di hadapan Khalifah, mereka melaporkan bahwa si lelaki itu telah membunuh seorang anggota masyarakat mereka. Lalu, si lelaki yang berada di belakang Khalifah itu berkata: "Wahai, Baginda Khalifah, saya memang membunuh si korban ketika ia tengah menyetubuhi isteri saya." Mereka membenarkan keterangan/pengakuan si lelaki itu. Akhirnya, Khalifah meraih pedang dari tangan si lelaki, kemudian mengibasngibaskannya di hadapan mereka. Rombongan orang itu kaget dan ketakutan sehingga lari terbirit-birit. Tak lama kemudian, Khalifah berpesan kepada si lelaki itu: “ Kalau nanti mereka kembali lagi, kamu temui saya lagi. ${ }^{10}$

- Pada suatu saat terjadi peristiwa di seseorang membunuh dengan sengaja orang lain, dan sang pelaku akhirnya tertangkap dan menjalani proses pemeriksaan. Pada kenyataannya, ahli waris si korban memaafkan sang pelaku, sehingga ia bebas dari pidana qisas. Meskipun demikian, Khalifah 'Umar ibn al-Khattab memutuskan bahwa sang pelaku telah bersalah dan dikenai pidana cambuk (100 kali cambukan) beserta pidana penjara selama 1 (satu) tahun. ${ }^{11}$ Dari praktik ini, dapat disimpulkan bahwa pidana qisasselain berfungsi sanksi pidana yang bersifat individual, yang bisa gugur lantaran adanya pemaafan wali/ahli waris si korban-juga berdimensi publik, menyangkut

9 Muhammad ibn Ahmad al-Ansari al-Qurtubi, al-fâmi' li Ahkam al-Qur'an, (Kairo: Dâr al- Kutub al-'Arabiyyah, 1989), Juz ke-10, h. 185.

${ }^{10}$ Badr al-Dîn al-'Aini, 'Umdat al-Qâriy Syarh Sahîh al-Bukhâriy, Juz ke-8, h. 190-191.

"I Ibn Hazm al-Andalusi, al-Muhalla, Juz ke- I0, butir masalah no. 2069.

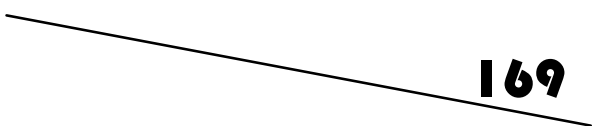


perlindungan kepentingan hidup masyarakat, sehingga negara/pemerintah tetap punya hak untuk memidana berupa pidana ta'zîr.

\section{3) Kebijakan Hukum Pidana Khalifah Usman}

- Khalifah 'Utsman ibn 'Affan pernah menjatuhkan pidana penjara atas Sabi' ibn Harits, gembong pencuri marga Tamim, hingga pada akhirnya ia meninggal dunia di rumah penjara itu. Hal ini diputuskan Khalifah dalam rangka memberikan hukuman tambahan kepada atas Sabi' ibn Harits yang sebelumnya sudah sudah dieksekusi dengan pidana amputasi tangan (pidana hadd). ${ }^{12}$

- Khalifah 'Utsman ibn Affan pernah mengambil kebijakan hukum, yakni menjatuhkan pidana mati (pidana ta'zir) terhadap orang yang mempraktikan sihir yang tidak mau bertaubat. ${ }^{13}$

- Terjadi peristiwa di mana seorang muslim membunuh dengan sengaja seorang kafir dzimmiy. Sesudah melalui proses pemeriksaan, Khalifah 'Utsman ibn 'Affan memutuskan bahwa sang muslim telah bersalah lantaran membunuh dengan sengaja sang kafir dzimmiy dan dikenai pidana qisas.

- Terjadi peristiwa di mana 'Ubaidillah ibn 'Umar membunuh al-Hurmuzan Yazdan. Hal ini dilakukan 'Ubaidillah karena ia punya prasangka bahwa al-Hurmuzan Yazdan itulah yang membunuh ayahnya,. Setelah diperiksa, ternyata alHurmuzan Yazdan adalah seorang lelaki yang hidup sebatang kara, tidak punya ahli waris. Menyikapi peristiwa itu, Ali ibn Abi Talib menyampaikan pandangan agar Khalifah 'Utsman ibn 'Affan menghukum'Ubaidillah dengan pidana qisas. Khalifah menolak pandangan'Ali ibn Abi Talib dengan beralasan: "Sungguh saya merasa malu,

${ }^{12}$ Ibrahim ibn Muhammad ibn Farhûn, Tabsirat al-Hukkâm, Juz ke-2, h. 117 dan 225

${ }^{13}$ Muhammad ibn 'Ali al-Syaukani, Nail al-Autâr Syarh Muntaqa al-Akhbâr, Jilid ke-7, h. 147 
karena ayahnya baru saja terbunuh pada hari kemarin, dan sekarang saya harus menghukum mati anaknya Maka, Khalifah 'Utsman ibn 'Affan memutuskan untuk memberi permaafan terhadap 'Ubaidillah, sang pelaku pembunuhan itu, dan membayar ganti rugi (diyat) yang dananya diambil dari kantor perbendaharaan Negara (bait al-mâl). ${ }^{14}$ Dari praktik ini, dapat disimpulkan bahwa dalam kasus pidana qisas, negara/pemerintah/hakim dapat memberi permaafan terhadap si pelaku pembunuhan bilamana sang korban tidak punya ahli waris. Dari praktik ini, dapat disimpulkan pula bahwa negara/pemerintah harus mengambil alih kewajiban pembayaran ganti rugi (diyat) dari si pelaku kejahatan yang tidak berkemampuan secara ekonomi.

\section{4) Kebijakan Hukum Pidana Khalifah Ali Bin Abi Thalib}

- Dihadapkan kepada Khalifah 'Ali ibn Abi Tâlib seorang anak kecil yang telah mencuri telur. Khalifah ragu apakah ia sudah balig atau belum. Maka, Khalifah memutuskan agar anak itu cukup dikenai hukuman amputasi jari tangan saja. ${ }^{15}$

- Terjadi peristiwa di mana seorang perempuan melakukan pernikahan dengan seorang lelaki, padahal ia masih berstatus isteri dari lelaki lain, di mana perihal statusnya ini disembunyikannya rapat-rapat. Pada akhirnya rahasianya ini terbongkar, sehingga kasus ini diajukan kepada Khalifah 'Ali ibn Abi Talib. Khalîfah memutuskan bahwa si perempuan dihukum dengan pidana rajm lantaran ia tahu dan sadar akan haramnya perbuatannya itu, sedang si lelaki dikenai hukuman cambuk 100 kali cambukan, bukan pidana rajm, lantaran ketidaktahuannya akan status si perempuan. ${ }^{16}$

- Terjadi peristiwa di mana datang empat orang melaporkan kasus perzinaan seorang lelaki dengan seorang perempuan

${ }^{14}$ Ibn al-Qayyim al-Jauziyyah, al-Turuq al-Hukmiyyah fi al-Siyâsah al-Syar'iyyah, h. 55-56.

${ }^{15}$ Muhammad ibn Idrîs al-Syâfi'i, al-'Umm, Juz ke-7, h. 168

${ }^{16}$ Muhammad ibn 'Ali al-Syaukâni, Nail al-Autâr Syarh Muntaqa al-Akhbâr, jlilid ke-7, h. 88.

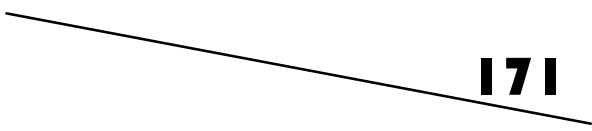


kepada Khalifah 'Ali ibn Abi Talib. Dalam proses pemeriksaan oleh Khalifah, tiga orang dari mereka menyatakan melihat dengan mata telanjang proses perzinaan tersebut, sedang satu orang lagi menyatakan hanya melihat si lelaki dan si perempuan tidur bersama dalam satu selimut. Atas dasar fakta demikian, Khalifah memutuskan bahwa ketiga orang tersebut dijatuhi pidana cambuk 80 kali cambukan karena terbukti berbuat qadzaf (tuduhan palsu zina); dan si lelaki dan si perempuan tersebut dikenai hukuman ta'zir lantaran tidur bersama antar orang yang bukan muhrim, bukan lantaran berzina. ${ }^{17}$

- Khalifah 'Ali ibn Abi Talib pernah mengambil kebijakan berupa instruksi kepada para Gubernur, yang pokok isinya ialah kemungkinan menjatuhkan vonis hukuman mati sebagai pidana ta'zir bagi terpidana peminum khamar yang meyakini kehalalannya dan bersikukuh dengan keyakinannya itu. ${ }^{18}$

- Terjadi peristiwa di mana seseorang memegang dengan kuat tubuh si korban yang sedang dikejar-kejar si pelaku, dan akhirnya si korban berhasil dibunuh oleh si pelaku. Sesudah melalui proses pemeriksaan, Khalifah 'Ali ibn Abi Talib memberikan putusan bahwa si pembuat langsung kematian si korban dikenai pidana qisâs dan orang yang memegang tubuh si korban dijatuhi pidana penjara seumur hidup, dan kemudian Khalifah 'Ali ibn Abi Talib menjelaskan: " Kamu telah memegang/menahan orang lain hingga tewas, maka saya putuskan untuk menahan kamu hingga meninggal dunia. ${ }^{19}$

- Terjadi peristiwa di mana pada suatu malam bulan madunya, seorang suami mendapati isterinya tengah berada di sisi kawannya yang laki-laki; sehingga sang suami marah

${ }^{17}$ Muhammad ibn Ahmad al-Ansâri al-Qurtubi, al-Jâmi‘ li Ahkâm al-Qur'ân, Juz ke-I2, h. 178

${ }_{18}^{18} \mathrm{Ibid}$, h. 299.

19 Muwaffaq al-Dîn ibn Qudâmah, al-Mugni, Juz ke-9, h. 24I. 
dan membunuh orang laki-laki tersebut; tetapi, sejurus kemudian, sang isteri kalap dan juga membunuh suaminya itu. Peristiwa ini dilaporkan kepada Khalîfah 'Ali ibn Abi Talib. Sesudah melakukan pemeriksaan, Khalifah memberi putusan bahwa sang isteri dihukum dengan dua macam hukuman, yaitu (1) pidana qisâs lantaran secara sengaja membunuh suaminya, dan (2) pidana ganti rugi (diyat) atas tewasnya kawan sang isteri lantaran dialah yang membawa sebab peristiwa itu. Khalifah 'Ali ibn Abi Talib menerangkan dengan lantang: " Dialah yang menjadi penyebab peristiwa pembunuhan tersebut. Dia lebih layak untuk dijadikan penyebab dibanding dengan suaminya yang memperbuat langsung, karena perbuatan sang suami diperkenankan oleh Syara' demi mempertahankan kehormatan diri. ${ }^{20}$

- Khalifah 'Ali ibn Abi Talib pernah mengambil kebijakan hukum, yakni unsur kesengajaan untuk menghilangkan nyawa orang lain tidak mungkin terwujud pada diri pelaku yang berpenyakit gila dan yang masih kanak-kanak, sehingga unsur kesengajaan tersebut sejajar dengan unsur kealpaan; dan pidana ganti rugi (diyat) harus dibayarkan oleh keluarga orang gila dan kanak-kanak itu. ${ }^{21}$

Setelah Periode Khulafaur rasyidin Hukum Pidana Islam terus berkembang seiring dengan jalannya peradaban dan sejarah ummat Islam dari masa-kesama mulai dari Rezim Dinasti Umayyah, Rezim Dinasti Abbasyiyas, Rezim Umayyah Andalusia, Dinasti Buwaih, Dinasti Fathimiyah Hingga akhir kekuasaan Rezim Turki Ustmani atau Rezim Ottoman.

\section{Pembaharuan Hukum Pidana Islam di Indonesia ?}

Pembaharuan hukum pidana pada hakekatnya mengandung suatu upaya untuk melakukan reorientasi dan reformasi hukum

${ }^{20}$ Subhi Mahmasâni, Turâts al-Khulafâ' al-Râsyidîn fi al-Fiqh wa al-Qadâ', h. 281

${ }^{21}$ Muhammad ibn 'Ali al-Syaukâni, Nail al-Autâr Syarh Muntaqa al-Akhbâr, jilid ke-7, h. 69

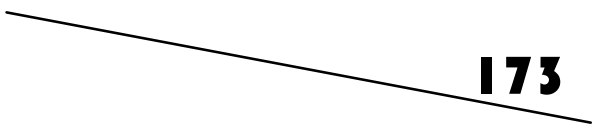


pidana yang sesuai dengan nilai-nilai sentral sosio-politik, sosiofilosofik dan sosio- kultural masyarakat Indonesia yang melandasi kebijakan sosial, kebijakan kriminal dan kebijakan penegakan hukum di Indonesia. ${ }^{22}$ Indonesia merupakan salah satu negara di dunia yang mayoritas penduduknya beragama Islam. Kurang lebih $89 \%$ penduduknya menganut agama Dalam ajaran yang diyakininya, terdapat sistem hukum Islam yang mengatur segala aspek kehidupan, termasuk yang terkait dengan hukum pidana.

Hukum pidana menurut van hammel adalah "semua dasardasar dan aturan-aturan yang dianut oleh suatu Negara dalam menyelanggarakan ketertiban hukum yaitu dengan melarang apa yang bertentangan dengan hukum dan mengenakan suatu nestapa kepada yang melanggar peraturan tersebut seperti KUHP yang di terapkan di Indonesia. secara umum sejarah hukum pidana di Indonesia dibagi menjadi beberapa periode yaitu;

\section{1) Periode Kerajaan Nusantara}

Pada masa kerajaan nusantara banyak kerajaan yang sudah mempunyai perangkat aturan hukum. Aturan tersebut tertuang dalam keputusan para raja ataupun dengan kitab hukum yang dibuat oleh para ahli hukum. Tidak dipungkiri lagi bahwa adagium ubi societas ibi ius sangatlah tepat. Karena dimanapun manusia hidup, selama terdapat komunitas dan kelompok maka akan ada hukum. Hukum pidana yang berlaku dahulu kala berbeda dengan hukum pidana modern. Hukum pada zaman dahulu kala belum memegang teguh prinsip kodifikasi. Aturan hukum lahir melalui proses interaksi dalam masyarakat tanpa ada campur tangan kerajaan. Hukum pidana adat berkembang sangat pesat dalam masyarakat.

Hukum pidana pada periode ini banyak dipengaruhi oleh agama dan kepercayaan masyarakat. Agama mempunyai peranan dalam pembentukan hukum pidana di masa itu. Pidana potong tangan yang merupakan penyerapan dari konsep pidana Islam

22 Barda Nawawi Arif, Bunga Rampai Kebijakan Hukum Pidana, (Citra Aditya Bakti, Bandung, 1996), h 325 
serta konsep pembuktian yang harus lebih dari tiga orang menjadi bukti bahwa ajaran agam Islam mempengaruhi praktik hukum pidana tradisional pada masa itu. ini membuktikan bahwa hukum pidana Islam pernah diterapkan di Nusantara pada Masa itu. ${ }^{23}$

\section{2) Periode Kolonial}

Pada masa periodisasi ini sangatlah panjang, mencapai lebih dari empat abad. Indonesia mengalami penjajahan sejak pertama kali kedatangan bangsa Portugis, Spanyol, kemudian selama tiga setengah abad dibawah kendali Belanda. Indonesia juga pernah mengalami pemerintahan dibawah kerajaan Inggris dan kekaisaran Jepang. Selama beberapa kali pergantian pemegang kekuasaan atas nusantara juga membuat perubahan besar dan signifikan dalam aturan hukum publik yang diterapkan di masyarakat.

Pola pikir hukum barat yang sekuler dan realis menciptakan konsep peraturan hukum baku yang tertulis. Pada masa ini perkembangan pemikiran rasional sedang berkembang dengan sangat pesat. Segala peraturan adat yang tidak tertulis dianggap tidak ada dan digantikan dengan peraturan-peraturan tertulis. Tercatat beberapa peraturan yang dibuat oleh pemerintah kolonial Belanda seperti statuta Batavia (statute vanbatavia). Berlaku dua peraturan hukum pidana yakni KUHP bagi orang eropa (weetboek voor de europeanen) yang berlaku sejak tahun 1867. Diberlakukan pula KUHP bagi orang non eropa yang berlaku sejak tahun 1873.

\section{3) Masa Kemerdekaan hingga Sekarang}

Selama lebih dari seratus tahun sejak KUHP Belanda diberlakukan, KUHP terhadap dua golongan warganegara yang berbeda tetap diberlakukan di Hindia Belanda. Hingga pada akhirnya dibentuklah KUHP yang berlaku bagi semua golongan sejak 1915. KUHP tersebut menjadi sumber hukum pidana sampai

${ }^{23}$ Ash-Shiddieqy, T.M. Hasbi. Sejarah dan Perkembangan Hukum Islam, (Jakarta: Bulan Bintang), 1971.

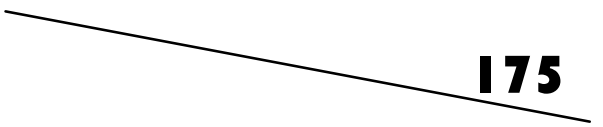


dengan saat ini. Pembentukan KUHP nasional ini sebenarnya bukan merupakan aturan hukum yang menjadi karya agung bangsa. Sebab KUHP yang berlaku saat ini merupakan sebuah turunan dari Nederland Strafwetboek (KUHP Belanda). Sudah menjadi konskwensi ketika berlaku asas konkordansi terhadap peraturan perundang-undangan.

KUHP atau wetboek van strafrecht merupakan kitab hukum warisan kolonial Belanda. Kitab ini ditetapkan dengan UU No. 1 Tahun 1946 dan dinyatakan berlaku berdasarkan UU No. 73 Tahun 1958. Draf revisi KUHP hanya terdiri dari Buku I tentang Ketentuan Umum dan Buku II tentang Tindak Pidana. Keseluruhan terdapat 41 bab dengan 737 pasal. Draf revisi ini tidak lagi membedakan tindak pinda kejahatan dan pelanggaran. Dalam makalah berjudul Pembaharuan Hukum Pidana Materiil Indonesia, Ketua Tim Revisi KUHP Prof. Muladi menyatakan, revisi ini tidak hanya dimaksudkan sebagai upaya dekolonialisasi, tapi juga rekodifikasi. Sejumlah peraturan perundang-undangan pidana yang berdiri sendiri disatukan di KUHP. Selain itu, dilakukan pula harmonisasi KUHP dengan perkembangan hukum pidana internasional. Revisi KUHP kini dilakukan secara sistemik dengan menyerap filosofi dan kultur yang ada di masyarakat. Dengan begitu,hukum Islam yang telah berkembang di tanah air bisa diadopsi pula ke dalam KUHP.

Jika menengok sejarah, hukum pidana Islam sudah pernah diberlakukan oleh beberapa kerajaan Islam di Jawa pada abad ke16. dalam catatan sejarah ditemukan banyak orang yang tangannya buntung karena dihukum potong tangan,. Hanya, pada masa kolonialisme, hukum pidana Islam nyaris tidak pernah diterapkan. Sejatinya, hukum pidana dengan Fiqh Jinayah ini memiliki banyak kesesuaian. "Tidak perlu dipertentangkan," semisal asas legalitas. Hukum pidana menegaskan, seseorang 
tidak bisa dihukum jika tidak ada aturan yang melarang perbuatan orang itu. ${ }^{24}$

Fiqh Jinayah juga punya asas demikian. Prinsipnya, seluruh perbuatan pada dasarnya boleh dilakukan, kecuali jika ada peraturan yang melarangnya. Salah satu konsep pertanggungjawaban pidana dalam Fiqh Jinayah yang bisa diadopsi KUHP adalah lembaga pemaafan. Seorang terdakwa bisa saja terbebas dari sanksi pidana jika ia dimaafkan oleh korban atau keluarga korban. lembaga pemaafan ini bisa diefektifkan untuk mengurangi jumlah penghuni lembaga pemasyarakatan (lapas). Bukan rahasia umum, kondisi lapas di negeri ini sudah overquote. Bukannya efektif menjadi lembaga rehabilitasi, lapas justru menjadi locus delicti bagi terjadinya tindak pidana, seperti tindak pidana narkotika. Belum lagi, negara harus menanggung biaya yang besar untuk menjamin kelangsungan hidup para narapidana. Draf revisi KUHP mulai memasukkan konsep itu. Meski tak sama persis, asas judicial pard on yang ada draf revisi KUHP memungkinkan seorang terdakwa mendapat ampunan dari majelis hakim. Namun, kewenangan hakim untuk memberi maaf diimbangi dengan asas culpa in causa yang memberi kewenangan hakim untuk tetap mengganjar terdakwa walaupun ada alasan penghapus pidana. Hal lain dari Fiqh Jinayah yang bisa diadopsi ke dalam KUHP adalah konsep diyat. "Ini berbeda dengan konsep denda dalam hukum pidana.

Diyat adalah pembayaran dalam jumlah tertentu yang harus diberikan terdakwa kepada korban atau keluarganya. Sedangkan denda harus diberikan kepada negara. Dari beberapa segi, konsep diyat ini dinilai lebih pas memulihkan hak-hak korban tindak pidana. "Kalau yang dirugikan adalah korban, kenapa justru negara yang menerima denda dari terdakwa. Membumikan hukum pidana Islam bukanlah pekerjaan yang mudah. Dibutuhkan peran negara karena berkaitan dengan hukum publik.

${ }^{24}$ Ibid, hal 30

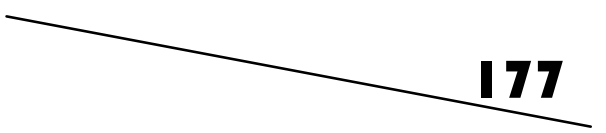


Ini berbeda dengan penerapan hukum perdata Islam. Mesir, misalnya, sejak 1940-an menegaskan dalam konstitusinya bahwa satu-satunya sistem hukum yang dipakai di Negara Piramida itu adalah hukum Islam. Namun faktanya tak seluruh hukum Islam diterapkan di sana. Yang diberlakukan secara menyeluruh hanya hukum perdata Islam. Sementara hukum publiknya tetap mengacu kepada hukum warisan Perancis.

\section{Penutup}

Dari uraian dan deskripsi yang terkait dengan Topik Pembaharauan Hukum Pidana Islam sebagaimana yang telah dipaparkan diatas, maka terdapat beberapa natijah dan catatan yang perlu untuk ditelaah lebih lanjut;

- Rasulullah SAW telah meletakkan dasar-dasar hukum Islam baik pada periode Mekkah maupun Periode madinah berdasarkan wahyu yang terekam dalam al-Qur'an maupun alSunnah.

- Karakteristik pewahyuan peiode Mekkah lebih bersifat seruan universal sedangkan pada periode Madinah cenderung bersifat primordial, sehingga pola penerapan hukum secara efektif terlaksana pada periode madinah termasuk yang terkait dengan persoalan hukum pidana Islam.

- Khulafa' al-Rasyidin telah banyak melakukan pembaharauan hukum Pidana Islam yang didasarkan pada kemaslahatan melalui proses ijtihadiah.

- Inovasi Hukum Pidana Islam Pasca generasi sahabat tetap berlangsung terutama pada masa Tadwin / koodifikasi berbagai macam ilmu pengetahuan mulai abad ke Tujuh Masehi hingga akhir abad ke sebelas.

- Hukum Pidana Islam di Indonesia / Nusantara pernah diterapkan di beberapa kerajaan Islam Nusantara seperti Kesultanan Samudra Pasai yang menjadikan Karya Nuruddin al-Raniry sebagai rujukan hukum, begitu juga di masa kesultanan Demak maupun Kesultanan Mataram Islam. 
- Pembaharauan Hukum Pidana di Indonesia di era sekarang mutlak di butuhkan mengingat KUHP yang ada merupakan warisan colonial yang sebagaian muatannya tidak sesuai dengan karakteristik budaya bangsa, sehingga diharapkan generasi Bangsa saat ini merumuskan pembaharauan hukum Pidana yang sesuai dengan karakter, budaya dan keyakinan masyarakat Indonesia, termasuk mentransformasikan hukum Islam dalam pembentukan hukum Nasional.

\section{Daftar Rujukan}

Audah, Abdul Qodir., Tasyri' Jina'I Islami, Beirut Libanon: Al Muassasah Al Risalah. 2000 M.

Barda Nawawi Arif., Bunga Rampai Kebijakan Hukum Pidana, Citra Aditya Bakti, Bandung, 1996.

Badr al-Dîn al-'Aini., 'Umdat al-Qâriy Syarh Sahîh al-Bukhâriy, Beirut Libanon: Al Muassasah Al Risalah. 1987.

Djazuli, H.A., Figh Jinayat, Menanggulangi Kejahatan dalam Islam, Jakarta: PT Raja Grafindo Persada, 2000.

Ibn al-Qayyim al-Jauziyyah., al-Turuq al-Hukmiyyah fi al-Siyâsah alSyar'iyyah, Kairo: Dâr al-Kutub al-'Arabiyyah, 1985.

Ibn Hazm al-Andalusi., al-Muhalla, Kairo: Dâr al-Kutub al'Arabiyyah, 1988.

Ibrahim ibn Muhammad ibn Farhûn, Tabsirat al-Hukkâm, Kairo:

Dar al-Kutub al-'Arabiyyah, 1980.

Muwaffaq al-Dîn ibn Qudâmah., Al-Mugni, Beirut Libanon: Al Muassasah Al Risalah. 1978.

Muhammad ibn 'Ali al-Syaukâni., Nail al-Autâr Syarh Muntaqa alAkhbâr, Beirut Libanon: Al Muassasah Al Risalah. 1989.

Muhammad ibn Idrîs al-Syâfi'i., al-'Umm, Dar al-Fikr, Bairut Libanon, 1965.

Muhammad ibn Ahmad al-Ansari al-Qurtubi., al-Jâmi' li Ahkâm alQur'ân, Kairo: Dar al-Kutub al-'Arabiyyah, 1989. 
Subhi Mahmasâni., Turâts al-Khulafâ' al-Râsyidîn fi al-Figh wa alQadâ', Beirut: Dâr al- Malâyîn, 1984.

Wahbah Zuhaili., al-Qur'an al-karim; banaituhu al-tasyri'iyyah wa khasaisuhu al-hadlariyyat, Dar al-Fikr, Bairut Libanon, 1993. 